\title{
Strategies for Translating Lexical Repetition in Contemporary Novels for Teenagers
}

\author{
Karolina Buitkuvienè \\ crossref $\mathrm{http} / / / \mathrm{dx}$. doi.org/10.5755/j01.sal.0.20.1317
}

\begin{abstract}
The article, on the basis of contemporary novels for teenagers and their translations into Lithuanian, aims to analyse types of lexical repetition that is common in adolescent speech and to discuss strategies for translating it. The paper distinguishes lexical repetition into (1) types of repetition in dialogues and (2) types of repetition in narrative sections and characters' thoughts. The research shows that same-unit repetition and repetition with variation are the most common types of repetition in the novels and their translations. Furthermore, there are cases when repetition takes a form of a synonym, antonym, hyponym and paraphrasis. In addition, the present article examines such translation strategies for repetition as preservation, synonymy, substitution, paraphrase, nominalization, pronominalization, announcing the repetition, addition and omission. The study results have demonstrated that both the strategy of preservation and synonymy have been used most often. It is also important to highlight that the choice of the translation strategy in a particular case is a controversial issue. Sometimes it is important to use a combination of different translation strategies in order to create an aesthetic target text and to achieve a similar effect on the target readership.
\end{abstract}

Keywords: translation strategies, adolescent language, same-unit repetition, repetition with variation, preservation, synonymy.

\section{Introduction}

Translators play important roles as cross-cultural transmitters of culture, attempting to interpret concepts and speech as faithfully and accurately as possible. However, this is a particularly difficult task for translators because they often encounter the very problematic aspects of the translation of culture-specific items. This is also the case when the translation of adolescent language is in question.

Adolescent language has not been given much attention in linguistics so far. This is surprising, as Stenstrőm states,

considering the importance of the transition period between childhood and adulthood in terms of its effect both on physical and psychological development and on social and linguistic behaviour (Stenström et al., 2002, p.2).

Moreover, adolescent language may be a prime source of information about ongoing linguistic developments and influence on adult language (Andersen, 2001, p.7).

Adults usually complain about adolescent language, without being aware of exactly what it is that distinguishes teenage speech from the more standard language (Stenström et al., 2002, p.1). Among the characteristic features of teen speech such features as unfinished sentences, slang, vulgar words, jargon specific to this particular social group and lexical repetition should be mentioned. Many researches have been implemented concerning the translation of slang. However, other features of teen speech, notably repetition, have been rather neglected. It cannot be stated that linguists have ignored the research on repetition altogether. The issue of lexical repetition has been widely discussed by famous linguists such as Ben-Ari, 1998, Klaudy and Karoly, 2000, al-Khafaji, 2006, Tannen, 2007 and Genç, 2010. However, Lithuanian researchers have not concentrated much on repetition and it seems that further investigations in this field are necessary. Thus, the aim of the present research is to determine the major translation strategies used for rendering lexical repetition in contemporary novels for teenagers. In order to achieve the aim, the following objectives have been set: to provide theoretical framework of issues concerning lexical repetition and its translation; to present the main types of lexical repetition in adolescent language in literary discourse; to analyse the reasons for the usage of lexical repetition; and to make certain observations about how lexical repetition and its translation help produce an accessible target text and recreate similar effect on the target readership. The scientific methods applied in the analysis of this research are the following: the analysis of theoretical material has provided a possibility to review various issues concerning lexical repetition and its translation; contrastive method has proved its usefulness in studying different language structures and comparing them; descriptive method has allowed to describe the research results thoroughly; and statistical method has helped obtain the statistical results of the repetitions analysed.

\section{Theoretical Approaches to Lexical Repetition: Types, Purposes and Functions}

The act of repeating the same words, phrases or sentences in everyday life may be referred to something negative and boring (as quoted in Tannen, 2007, p.63). However, repetition is a highly-valued stylistic device in fiction and poetry where it performs various literary functions depending on genre, period and writer. As Ben-Ari has observed, repetition in literature may have a generic function, it may serve as a musical, thematic or symbolic device. Finally, it can function as a simulator of dialogues or spoken language in modern literature (Ben-Ari, 1998, p.69).

There are many theoretical assumptions concerning the issue of repetition, however, in this literature review the approach to lexical repetition introduced by Klaudy and 
Karoly (2000) and Tannen (2007) is considered as a central one. According to Klaudy and Karoly, the term repetition includes two concepts: one of cohesive relation, which occurs when words or phrases are repeated in exactly the same word order or almost the same; and the other concept is related to "the information content of the lexical unit", which occurs when repetition is expressed using different words or phrases, i.e., they can be expressed using "a synonym, opposite, hyponym/ superordinate, metonym or unit instantially related to a previously mentioned lexical unit" (Klaudy and Karoly, 2000, p.146). The linguists make a distinction between two types of repetition: sameunit repetition and different-unit repetition. Same-unit repetition is "a lexical unit repeated in exactly the same form, or with inflectional or derivational change" (ibid., p.146). Different-unit repetition, as the critics claim, is expressed using a synonym, antonym, hyponym, meronym and instantial relations. The researchers also single out simple and derived repetition. In Klaudy and Karoly's words, simple repetition is "the recurrence of the same lexical unit with possible inflectional difference", whereas derived repetition is defined as "the appearance of an identical root morpheme, but with possible derivational difference" (ibid., p.146). The phenomenon of repetition has also been a favourite topic for analysis to Tannen (2007). She focuses much on repetition in conversational discourse. Tannen makes a distinction between dialogues in real speech and those used in literary texts. The wellknown linguist emphasizes that literary texts tend to elaborate strategies that are spontaneous in conversation. Hence, the usage of repetition in fiction may be considered as a stylistic device applied to make a literary text more realistic and similar to everyday situations (Tannen, 2007, p.80) Repetition in dialogues may be divided into selfrepetition and allo-repetition. The former one concerns repetition when speakers repeat themselves, whereas the latter one deals with repetition of other speakers. Both selfrepetition and allo-repetition may be exact, varied or paraphrase. In addition, repetition can be immediate or delayed (Tannen, 2007, pp.63-64).

While repeating the same things or reading the repeated ones, few of us consider the reasons for the usage of lexical repetition. According to Tannen, the main purposes served by repetition are conversation production, comprehension, connection and interaction. In other words, they enable us to avoid silence during a conversation, to better understand the presented information, help achieve text cohesion and stimulate fruitful interaction between speakers (Tannen, 2007, pp.58-61). Referring to Genç, the purposes of repetition are closely connected with the functions of repetition, which may be put under the following categories: participatory listenership, ratifying listenership, humour, savouring, stalling, expanding, participating, evaluating through patterned rhythm and bounding episodes (Genç et al., 2010, p.217, Tannen, 2007, p.67).

To sum up, repeating the same words or phrases in everyday life may be considered as a negative thing, since repetition is associated with boredom. However, it is a highly-valued stylistic device in fiction, performing various functions and contributing to the creation of an aesthetic target text. Furthermore, lexical repetition may serve as a means to make a literary text more realistic to everyday situations. Finally, it can be stated that repetitions help us avoid silence during a conversation, to better comprehend the information heard or read, and it enables us to stimulate mutual interaction between speakers.

\section{Strategies for Translating Lexical Repetition in Fiction for Teenagers}

Translation of fiction is a difficult task for translators because they, as Helgregen states, have to consider that they take one text out of its cultural context and bring it into a foreign context (Helgregen, 2005, p.9). Thus, translators have to decide how far to go in either domesticating or foreignizing the target text (Davies, 2003, p.69). According to Tabbert, over the years the translation studies community has started to favour the target-oriented approach that pays attention on readability and achieving an equivalent effect in the target culture (Tabbert, 2002, p.303). This is also to be considered when the translation of adolescent fiction is dealt with. In order to achieve a similar effect on the target readership, the translators of fiction for teenagers have to know current trends in teen culture, otherwise they will fail to produce an interesting literary text. As Davies aptly puts it,

\begin{abstract}
translating for children may present more of a challenge than translating for adults; young readers are perhaps less likely to be tolerant of the occasional obscurity, awkwardness or unnatural-sounding phrasing which adults, conscious that they are dealing with a translation, may be more accepting of (Davies, 2003, p.66).
\end{abstract}

On the other hand, Shavit argues that books for children and their translations can have greater "liberties regarding the text because of the peripheral position children's literature occupies in the polysystem" (Shavit, 1981, p.171). Thus, the translators may want to make more alterations regarding the target text. All in all, the texts should be translated in such a way as to achieve three functions, namely expressive, informative and vocative (Newmark, 1988). In order to make the reader react in the way intended by the text, the translators resort to different translation strategies.

Referring to critical sources, such translation strategies as preservation, synonymy, substitution, paraphrase, nominalization, pronominalization, addition, announcing the repetition and omission may be distinguished for translating lexical repetition (Ben-Ari, 1998; Davies, 2003; al-Khafaji, 2006). Davies identifies the strategy of preservation as a method by which "a translator maintains the source text term in the translation" (Davies, 2003, p.73). In case of the translation of lexical repetition, the strategy of preservation may be considered as a method, which renders a precise repetition of the original in the target text. The strategy of synonymy is a method of rendering repetition by a synonym. Similar to synonymy is the strategy of substitution, which can be described as a replacement of one word that was repeated in the source text by another word in the target text conveying the same meaning as in the source text. al-Khafaji also presents the strategy of paraphrase, which involves rendering of source text lexical repetitions by a paraphrase translation in the target text. In addition, the linguist determines the strategy 
of nominalization and pronominalization, where the latter one is a technique of translation when a personal pronoun in the target text is replaced by the proper noun of its referent, whereas the former one is the opposite process (al-Khafaji, 2006, pp.46-56). Ben-Ari introduces the strategy of addition when new repetitions are introduced due to some reasons, e.g. an attempt to compensate for repetitions that were omitted or with the aim to embelish the language of a literary text (Ben-Ari, 1998, p.77). When the translators are unable to eliminate repetition altogether, then they have to resort to the strategy of announcing the repetition, i.e., the translators have to think about a different way of stating that repetition still exists. The last strategy, which may be employed for translating repetition, is omission or cancelling repetition, to use Ben-Ari's term. It also helps reduce the number of repetitions in the target text (BenAri, 1998, p.72; Davies, 2003, p.79). All these strategies are considered in the research while analysing the major tendencies in the translation of lexical repetition.

Generalising the above-presented theoretical assumptions, it can be claimed that the translation of adolescent literature is a challenge for the translators as they have to know current trends in teen culture, otherwise a boring literary text will be created. On the other hand, having in mind that the readership is teenagers, the translators may feel free to make more alterations regarding the target text. This is also the case when the translation of lexical repetition, which is common in adolescent speech, is dealt with. In order to make the reader react in the way intended by the text, the translators resort to such translation strategies as preservation, synonymy, substitution, paraphrase, nominalization, pronominalization, announcing the repetition and omission while rendering lexical repetition.

\section{Methodology of the Research}

The research is aimed at analysing lexical repetition, categorising it into particular types, identifying the function that repetition performs in fiction for teenagers and determining the strategies for the translation of repetition. The research material has been taken from Green's Looking for Alaska (2005), translated by Gadeikis in 2010, and Burgess's Junk (2003), translated by Patiomkinas in 2002. The selected lexical repetition is grouped under two categories: (1) repetition in characters' thoughts and narrative sections referring to Klaudy and Karoly's theory (2000) and (2) repetition in dialogues according to Tannen's (2007) theory. The scope of the research is 142 instances: 83 instances in narrative sections and 59 instances in dialogues. The analysis of the selected instances allows to make certain observations and to present major findings at the end of the paper.

\section{Types of Lexical Repetition in Characters' Thoughts and Narrative Sections}

The selected examples of lexical repetition in characters' thoughts and narrative sections of the novels show that most examples of repetition are same-unit repetitions, which may be defined as exact repetitions (49 examples). It means that the same words of the source text are repeated in the translated text, though there may be changes in inflections or parts of speech. The following examples below illustrate it. 1. Need I say? Need I say how livid I was? The old bastard
had rung up and terminated my job for me (Burgess, 2003,
p.15).

2. I had a nice little job serving tea to tourists. Actually, looking back, it wasn't a nice little job at all, it was slave labour (Burgess, 2003, p.14).

3. The thing was, if I spent my money on ice-cream I'd have to go into town and beg in the pedestrian precinct - the Dust Bowl, they call it - so I could get something to eat that night. And begging is so grim (Burgess, 2003, pp.26-27).

4. I hated sports. I hated sports, and I hated people who played them, and I hated people who watched them, and I hated people who didn't hate people who watched them or played them (Green, 2005, p.58).

5. She cooked a small mountain of artichoke dip. She festooned our living room in green and yellow streamers, the colours of my new school. She bought two dozen champagne poppers and placed them around the edge of our coffee table (Green, 2005, p.9).

The presented examples are same-unit, simple repetitions, i.e., the same words are repeated in the successive sentences. The exception is Example 3 when the part of speech is changed. The verb beg is changed into the noun begging in the following utterance. The latter repetition may be defined as same-unit, derived repetition. As to quote Klaudy and Karoly, derived repetition is defined as "the appearance of an identical root morpheme, but with possible derivational difference" (Klaudy and Karoly, 2000, p.146). All sentences, except Example 5, are emphatic because, by repeating the same things, the narrators wish to express their characters' excessive emotions or negative feelings toward a certain situation. In addition, Example 2 reveals that the character of the novel is both dissatisfied and ironic about her nice little job. The repetition of the personal pronoun she in Example 5 may be an instance of a listing function. It also slows down the reading tempo and intends at creating the feeling of boredom that the character of the novel Miles experiences while watching his mother's preparation for a farewell party.

The other two most common types of lexical repetition in the novels and their translations are repetitions rendered by synonyms (19 examples) and antonyms (8 examples). In Oxford English Reference Dictionary (1996), synonym is defined as a word or phrase that means exactly or nearly the same as another in the same language, whereas antonym is described as a word opposite in meaning to another in the same language.

6. I didn't go back that day. In fact, I stayed away all weekend as a protest (Burgess, 2003, p.17).

7. Once or twice I've seen the alkies with women with them, but you never see any young women in there. The girls all sleep out in doorways, in public... (Burgess, 2003, p.32)

8. So I spent the whole day looking at my dad's globe for a really cool name. And so my first choice was Chad, like the country in Africa. But then my dad said that was a boy's name, so I picked Alaska (Green, 2005, p.67). 
9. I'd been feeling pretty down - being away from home, being on my own. Now I felt great (Burgess, 2003, p.26).

10. It used to be all right. I mean, it was awful but it wasn't horrible (Burgess, 2003, p.61).

The examples above are different-unit, simple repetitions rendered by synonyms (Example 6, 7) or antonyms (Example 9, 10). Example 8 is a case of different-unit, derived repetition where the noun choice is changed into a synonym that takes a form of the verb picked. It is evident that lexical repetition rendered by synonyms serve the stylistic purpose. Sometimes repetition may be considered as a demerit of style, thus the authors try to reduce it by using synonyms. Repetition rendered by antonyms serve the function of emphasis. By using words or phrases of an opposite meaning, the characters are able to show the real situation they face and their attitude toward it.

Lexical repetition rendered by a hyponym (3 examples) and instantial relations (4 examples) is the last group of instances found in adolescent literature. However, these repetitions are the occasional ones. A hyponym is defined in linguistics as a word or phrase whose semantic range is included within that of another word, e.g., scarlet, vermilion, carmine, and crimson are all hyponyms of red (their hypernym), which is, in turn, a hyponym of colour (Webster's online dictionary). The term instantial relations, as referred to Klaudy and Karoly, occurs when "a unit is instantially related to a previously mentioned lexical unit" (Klaudy and Karoly, 2000, p.146).

11. I stood there for a bit and felt like I was soaking up that colour. I love yellow. It's the colour of sunlight (Burgess, 2003, p.27).

12. The Eagle looked down and bit his lower lip. 'Last night, Alaska Young was in a terrible accident.' His tears came faster, then. 'And she was killed. Alaska has passed away' (Green, 2005, p.167).

Example 11 demonstrates the case of hyponymy, which is "the relation between two lexical units in which the meaning of the first is included in that of the second" (Matthews, 1997, p.167), i.e., colour is a larger term that includes yellow. Example 12 is the case of instantial relations where she is instantly referred to Alaska. Such kind of repetition is only possible in two sentences following each other, because in the other part of the text she might not necessarily refer to Alaska. It may be stated that Example 11 performs the function of savouring, as the repeated words enable us to see that colour and have certain associations with warmth. In Example 12 the emphatic function is evident. By repetition the narrator does not allow us to forget that Alaska is dead.

The total number of examples of lexical repetition in the narrative sections is presented below in Table 1 .

Table 1. Types of Lexical Repetition in Narrative Sections.

\begin{tabular}{|c|l|c|c|}
\hline No. & \multicolumn{1}{|c|}{ Type } & $\begin{array}{c}\text { Number of } \\
\text { examples }\end{array}$ & Percentage,\% \\
\hline 1. & Same-unit repetition & 49 & 59 \\
\hline 2. & $\begin{array}{l}\text { Different-unit } \\
\text { repetition: synonymy }\end{array}$ & 19 & 23 \\
\hline
\end{tabular}

\begin{tabular}{|c|l|c|c|}
\hline 3. & $\begin{array}{l}\text { Different-unit } \\
\text { repetition: opposites }\end{array}$ & 8 & 9 \\
\hline 4. & $\begin{array}{l}\text { Different-unit } \\
\text { repetition: hyponymy }\end{array}$ & 3 & 4 \\
\hline 5. & Instantial relations & 4 & 5 \\
\hline
\end{tabular}

Translation Strategies for Lexical Repetition in Characters' Thoughts and Narrative Sections

Translation is, in the words of Newmark, "rendering the meaning of a text into another language in the way that the author intended the text" (Newmark, 1988, p.5). However, it is a challenge to the translators, since there is no absolute correspondence between two languages. Hence, it may be claimed that fully exact translations cannot exist (Nida, 2000, p.126). When discussing the issues of the translation process, it is important to note the translation universals, namely explicitation, normalization and simplification, which often have an effect on the translation process (Helgegren, 2005, p.12). According to Baker, the universal features come natural in the process of translation, since "the nature and pressures of the translation process must leave traces in the language that translators produce" (Baker, 1996, p.177). It is interesting to analyse whether these translation universals contribute to the creation of a less complex literary text for adolescents, and to discuss whether the translation strategies are used more freely in order to create an easy-read target text. Finally, it is important to explicate if the translation universals are applied seeking repetition reduction.

The selected examples of lexical repetition and their translation show that the strategy of preservation (37 cases) is most common in dealing with repetition in literary texts. For example:

13. I stood there staring at it, and I had an idea for a painting. A dandelion - just one huge bright dandelion. The background was all black and the dandellion was all the bright yellows and oranges, every petal a long yellow triangle. (Burgess, 2003, p.28)

Stovejau spoksodamas i pienes, ir staiga man šove $i$ galva paveikslo ideja. Jame turèjo büti pienè, vienui viena milžiniška pienè juodame fone. Gelsvai oranžinè pienè ilgais trikampiais vainiklapiais (Burgess, 2002, p.27).

14. Need I say? Need I say how livid I was? The old bastard had rung up and terminated my job for me (Burgess, 2003, p.15).

Ar dar reikia ka sakyti? Ar reikia sakyti, kaip aš persiutau? Tas senbezda paskambino ir užraukè man darba!! (Burgess, 2002, p.18).

15. I hated sports. I hated sports, and I hated people who played them, and I hated people who watched them, and I hated people who didn't hate people who watched them or played them (Green, 2005, p.58).

Nekenčiau sporto. Nekenčiau sporto, nekenčiau sportininku, nekenčiau sporta žiürinčiu žmoniu ir nekenčiau žmoniu, kurie pakentè sportuojančius arba sporta stebinčius žmones (Green, 2010, p.63).

16. After all this time, it still seems to me like straight and fast is the only way out - but I choose the labyrinth. The labyrinth blows, but I choose it (Green, 2005, p.257). 
- Po visko, kas jvyko, man pradeda atrodyti, kad tiesiai ir greitai yra vienintelis kelias, - bet aš renkuosi labirinta. Labirintas yra šūdas, bet aš renkuosi ji (Green, 2010, p.291).

In the examples above both Patiomkinas and Gadeikis decide to retain repetition of the original texts with the aim to produce a natural-sounding text and in this way to create a similar effect on the target readership. In Example 14 we notice that an extra word dar is added. The use of it serves for the much more intensified effect on the reader's emotions.

The strategy of synonymy (21 cases) is another most common translation strategy applied by the translators for rendering repetition. The following examples below illustrate it.

17. When I'd finished no one said a word, but then Richard got up and gave me a big hug, then Vonny ... even Jerry got up and hugged me. It was ... it wasn't like they knew me so well or anything, and it felt a bit awkward at first because I'm not ... my family doesn't hug much (Burgess, 2003, p.70).

Kai baigiau pasakoti, visi sédèjo tylūs, bet paskui Ričardas priejęs stipriai suspaudè glèby, tada Vone....Netgi Džeris atsistojo ir apkabino mane. Jie...Jie manęs gerai net nepažinojo, ir iš pradžiu jaučiausi truputị nepatogiai, nes aš... Mano šeimoje nesiglèbesčiuojama (Burgess, 2002, p.58).

18. I sneaked out about ten. Mum was upstairs and Dad was out at the supermarket. I walked out of the house and down the road to the coach station (Burgess, 2003, p.78).

Išsmukau iš namu apie dešimtą. Mama sèdejo antrame aukšte, o tètis, buvo išvažiavęs i prekybos centrą. Nudrožiau gatve i autobusu stoti (Burgess, 2002, p.64).

19. This teacher rocked. I hated discussion classes. I hated talking, and I hated listening to everyone else stumble on their words and try to phrase things in the vaguest possible way so they wouldn't sound dumb, and I hated how it was all just a game of trying to figure out what the teacher wanted to hear and then saying it (Burgess, 2003, p.43).

Šitas mokytojas kietas. Nekenčiau diskusiju per pamokas.

Nemègau kalbèti ir nemégau klausytis, kaip kiti springsta žodžiais, bandydami išsakyti savo mintị kuo aptakiau, kad tik nepasirodytu kvaili, ir nekenčiau, kad tokio žaidimo esmé viso labo perprasti, kq nori išgirsti mokytojas (Burgess, 2002, p.46).

The examples above show that lexical repetition of the source text is rendered by synonyms in the target text. It is said to be very helpful if the translators decide to resort to a universal of translation, i.e., normalization. Notwithstanding the importance of repetition in literary texts, it occurs that avoiding repetition is one of the most persistent norms in translation. The use of synonyms has to do with the wish to display richness of vocabulary, since meagerness of vocabulary is not appreciated. Moreover, it can be claimed that it is especially significant in western civilizations where the use of sophisticated vocabulary was a sign of superiority (Ben-Ari, 1998, p.70). The Lithuanian culture also has an aversion for repetitions, thus the translators usually reduce them by using synonyms.

It is quite common to maintain repetition in the target texts by the use of such translation strategies as substitution (5 cases) and paraphrase ( 8 cases).
20. I kept thinking of the rows they must be having. I kept thinking about how angry he was going to get, how he'd tell her she'd driven me away... (Burgess, 2003, p.65).

Negalëjau negalvoti apie kivirčus, be kuriu jie tikriausiai neapseina. Isivaizduodavau, kaip tètis siunta ir kaltina mama, kad ji mane išgynusi iš namu (Burgess, 2002, p.54).

21. The trouble was, I kept thinking I'd feel better if I spoke to her; but I knew it wasn't true. I'd left her a note when I went but that was ages ago. It was Gemma's ideas not to ring her for a bit. She said my mum'd just make me feel really bad, maybe she'd even talk me into coming back (Burgess, 2003, p.34).

Tačiau negalejau atsikratyti ịkyrios minties, jog pakalbejęs su ja pasijusiu geriau. Žinojau, kad netiesa, išvažiuodamas palikau jai rašteli, tačiau atrodè, jog tai atsitiko kaži kada. Man Džema patarè kuri laika neskambinti mamai. Sake, jog po pokalbio nuotaika dar labiau subjurs, galbūt ji netgi ịkalbinès mane sugrịžti (Burgess, 2002, p.32).

22. Then Tar started to follow me about going, 'Is anything wrong? What's the problem, Gemma?' (Burgess, 2003, p.139).

Vèliau Taras èmé sekioti man iš paskos klausinėdamas, kokia bitè igèlusi (Burgess, 2002, p.107).

In Example 20 we can see the case of substitution where negalejau negalvoti is changed into isivaizduodavau. It is sometimes very difficult to distinguish between synonymy and subsitution. They are similar in the sense that the word in the target text still has to convey the same meaning as in the original text. Example 21 and Example 22 show how repetition is reduced by a paraphrase counterpart in the target text, i.e., feel really bad is rendered by nuotaika dar labiau subjurs, whereas what's the problem is changed into klausineddamas, kokia bitè igèlusi.

The next strategy used for translating repetition is announcing the repetition (4 cases). On the one hand, it helps to avoid repetition and to conform to normative stylistics. On the other hand, repetition, still existing in the translations, helps retain some of the original stylistic effect. The examples below show the translators' successful try not to repeat the same words.

23. I know what you're thinking about me and my mum. Apron strings. But it wasn't like that. I think it wasn't like that (Burgess, 2003, p.61).

Nutuokiu, ka manot apie mane ir mano mama: kad ji laike mane po padu. Nieko panašaus, bent jau aš taip manau (Burgess, 2002, p.51).

24. 'Don't you trust me, David? Don't you trust me?' she kept saying. And of course I didn't but I could never say, 'No, I don't trust you,' so I had to make excuses (Burgess, 2003, p.69).

- Tu manimi nepasitiki, Deividai? Tu manimi nepasitiki? kartojo ji. Žinoma, kad ne, bet aš niekada negaléčiau jai to tiesiai pasakyti (Burgess, 2002, p.57).

25. We talked and talked... I don't know how long we talked (Burgess, 2003, p.149).

Mes kalbëjomès ir kalbëjomès... Nežinia kiek laiko (Burgess, 2002, p.114).

The final translation strategy used for repetition reduction is omission or cancelling repetition ( 8 cases). It is most 
common in case of rendering pronouns from English into Lithuanian. The main reason for the omission of pronouns lies in that in Lithuanian the inflections of the verb show the person you refer to, thus, the pronouns, which are necessary in English texts, may be omitted in Lithuanian. Furthermore, the stylistic aspect should be considered, too. The overuse of pronouns may devalue the aesthetics of the literary text, thus the translators tend to eliminate them. For example:

26. She cooked a small mountain of artichoke dip. She festooned our living room in green and yellow streamers, the colours of my new school. She bought two dozen champagne poppers and placed them around the edge of our coffee table (Green, 2005, p.9).

Ji paruošè dubenị artišoku padažo. Išpuošè svetainę žaliomis ir geltonomis - mano naujosios mokyklos spalvu juostelèmis. Nupirko pora tuzinu papliaušku ir sustate jas apie kavos staliuka (Green, 2010, p.9).

27. I hadn't thought. I was being selfish. I couldn't ask Gemma to come and live like this with me (Burgess, 2003, p.33).

Kaip nepagalvojau. Savanaudis. Negalima kviesti Džemos gyventi tokiame lauže (Burgess, 2002, p.31).

Finally, it can be stated that the choice of the translation strategy in a particular case is a controversial issue. Sometimes it is important to use a combination of different strategies in order to create a similar effect on the target readership.

The main strategies for translating lexical repetition in the narrative sections are presented below in Table 2 .

Table 2. Strategies for Translating Repetition in Narrative Sections.

\begin{tabular}{|c|l|c|c|}
\hline No. & \multicolumn{1}{|c|}{ Strategy } & $\begin{array}{c}\text { Number of } \\
\text { examples }\end{array}$ & $\begin{array}{c}\text { Percentage, } \\
\%\end{array}$ \\
\hline 1. & Preservation & 37 & 44 \\
\hline 2. & Synonymy & 21 & 25 \\
\hline 3. & Substitution & 5 & 6 \\
\hline 4. & Paraphrase & 8 & 10 \\
\hline 5. & Announcing repetition & 4 & 5 \\
\hline 6. & Omission & 8 & 10 \\
\hline
\end{tabular}

Types of Lexical Repetition and Translation Strategies for Repetition in Dialogues

The next issue under discussion is lexical repetition in the dialogues. It is categorized according to Tannen's (2007) theory. In conversational discourse repetition is divided into self-repetition and allo-repetition. Both categories may be immediate or delayed. Immediate repetition usually occurs in the next utterance or even in the same sentence, whereas delayed repetition is found later in the dialogue (Tannen, 2007, pp.63-64). With reference to Tannen's theory (2007), three kinds of repetition in the dialogues are distinguished, i.e., exact (18 examples), repetition with variation (31 examples) and paraphrase (10 examples).

The examples of exact repetition are presented below (see Table 3 and Table 4).
Table 3. Exact Repetition in Conversational Discourse.

\begin{tabular}{|c|}
\hline Burgess, 2003 \\
\hline $\begin{array}{l}\text { 28. Lily: "I'm not gonna kill my baby. That's my baby. No } \\
\text { one's gonna kill my baby." }\end{array}$ \\
\hline Gemma: "I didn't say kill it." \\
\hline $\begin{array}{l}\text { Lily: "I said, I'm going to have a baby. I'm going to have it. } \\
\text { There's gonna be a baby. A baby, Gems..." (p. 247). }\end{array}$ \\
\hline Burgess, 2002 \\
\hline $\begin{array}{l}\text { Lilè: - Aš neketinu žudyti savo küdikio. Jis mano. Niekas jo } \\
\text { nenužudys. }\end{array}$ \\
\hline Džema: - Aš tau neliepiau jo žudyti. \\
\hline $\begin{array}{l}\text { Lilè: - Dar karta sakau: aš nežudysiu savo vaikelio. Aš ji } \\
\text { pagimdysiu. Tai bus mano vaikutis. Vaikutis, Džema.... } \\
\text { (p.190). }\end{array}$ \\
\hline
\end{tabular}

Table 4. Exact Repetition in Conversational Discourse.

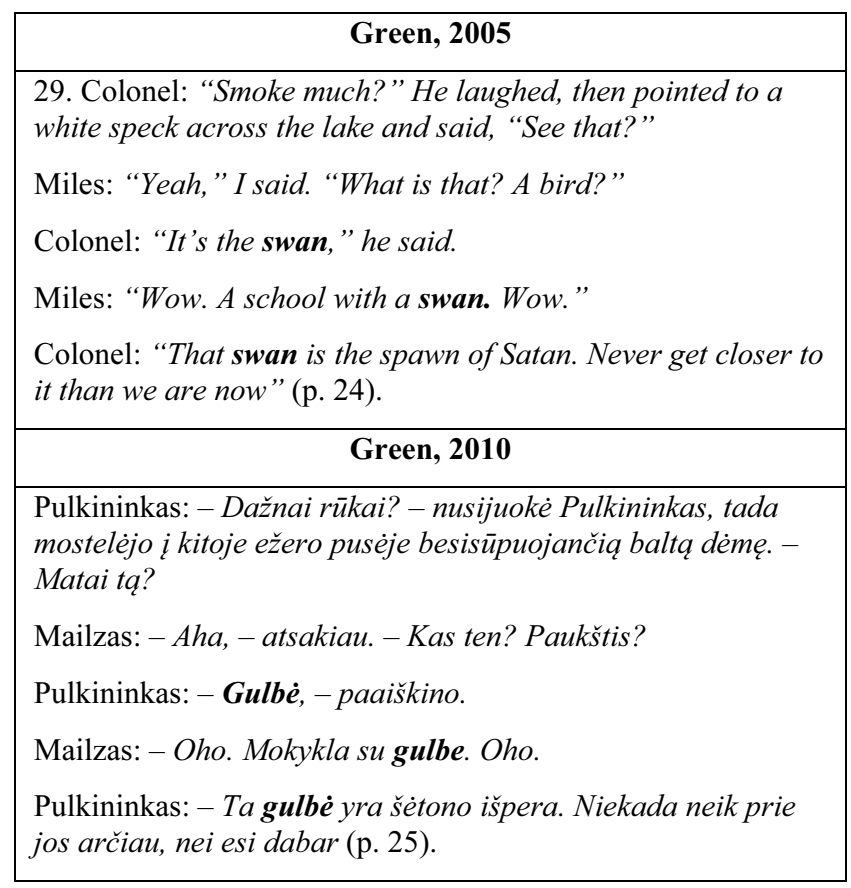

Both dialogues in Table 3 and Table 4 present examples of exact repetition. In the dialogue between Lily and Gemma, we find immediate, self-repetition as Lily is the one who repeats herself, and repetition occurs in two successive sentences. The dialogue between Colonel and Miles is an example of immediate, allo-repetition. It is not difficult to determine the functions that both dialogues perform. In the dialogue between Lily and Gemma, Lily speaks emotionally about her pregnancy. Though Lily is addicted to drugs, she is determined to keep her baby. Thus, she repeats the word baby several times in order to ratify her intentions. The repetition of the word swan in the dialogue between Colonel and Miles performs the function of participatory listenership, which links both speakers in the conversation and in relationship. Looking at the translations, it may be pointed out that the strategy of synonymy in Burgess's example is applied where baby is rendered by $\boldsymbol{k} \overline{\boldsymbol{u}} \boldsymbol{d i k i s}$, vaikelis, vaikutis, whereas the second dialogue shows that the strategy of preservation is used where gulbe is repeated three time in the successive sentences. 
The second type of repetition in the dialogues is repetition with variation. Repetition with variation is defined as such when

questions are transformed into statements, statements changed into questions, repetition with a single word or phrase changed, and repetition with change of person or tense (Tannen, 2007, p.63). For example:

Table 5. Repetition with Variation in Conversational Discourse.

\begin{tabular}{|c|}
\hline Burgess, 2003 \\
\hline $\begin{array}{l}\text { 30. Vonny: "But they must be feeling awful. At least you could } \\
\text { let them know you're all right." }\end{array}$ \\
\hline $\begin{array}{l}\text { Gemma: "And tell them when to expect me back?" I asked. } \\
\text { 'And to send on the wooly vests." }\end{array}$ \\
\hline $\begin{array}{l}\text { Vonny: “No, like I said — just let them know you're okay.” } \\
\text { (p.88). }\end{array}$ \\
\hline Burgess, 2002 \\
\hline $\begin{array}{l}\text { Vonis: - Jie turètu jaustis siaubingai. Galètum bent nuraminti } \\
\text { juos. }\end{array}$ \\
\hline $\begin{array}{l}\text { Džema: - Ir pranešti, kada tikètis mane sugrižtančios? Ir } \\
\text { paprašyti atsiųsti vilnoniu apatinių? }\end{array}$ \\
\hline $\begin{array}{l}\text { Vonis: - Ne, jau sakiau-nuramintum, kad esi gyva ir sveika } \\
\text { (p.71). }\end{array}$ \\
\hline
\end{tabular}

Table 6. Repetition with Variation in Conversational Discourse.

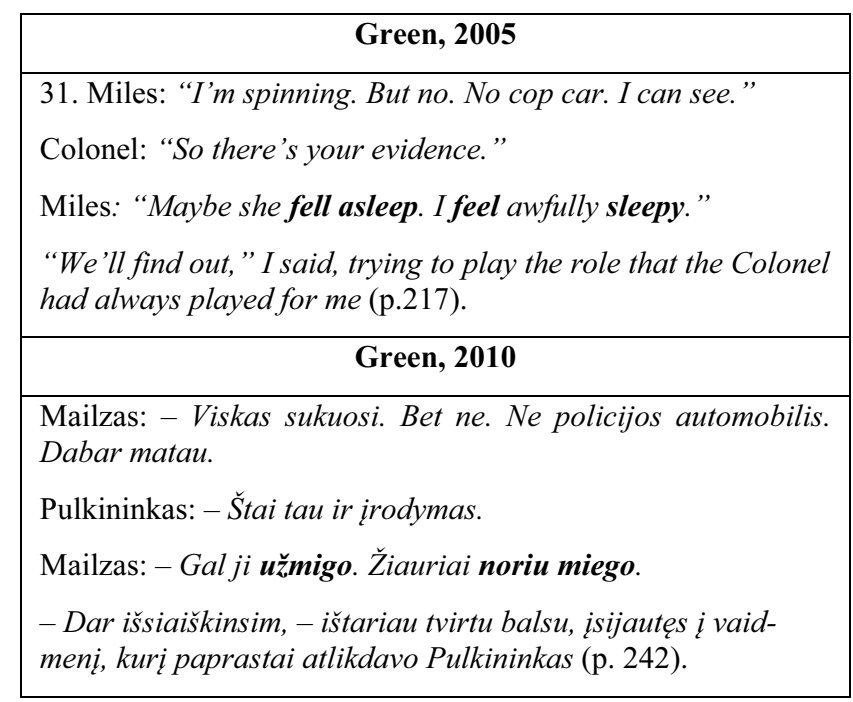

The dialogues above show examples of repetition with variation. In the dialogue between Vonny and Gemma, we see that only one word of the phrase is changed, i.e., all right is changed into ok. In the dialogue between Miles and Colonel, the phrase fell asleep is rendered by feel sleepy in the next sentence. Here we may notice a tense shift. In addition, both examples of repetition are immediate, self-repetitions. Considering the functions of repetition, the emphatic function is evident in Burgess's dialogue where Vonny, repeating the same phrase with slight variation, wants to emphasize that it is highly significant to inform Gemma's parents about her place of residence. The repetition in the dialogue between Miles and Colonel represents the function of stalling. Miles wants to find out how Alaska died, but he is lost and confused. By repeating the same words, he just stalls for time in order to present some new facts. In this way, the readers are made to stop and make certain guesses about Alaska's mysterious death as well. Looking at the translations, it can be noted that both Patiomkinas and Gadeikis applied the strategy of preservation.

The last kind of repetition is paraphrase when a repeated sentence contains analogous ideas but they are expressed in different words. The cases of paraphrase are presented below (see Table 7 and Table 8).

Table 7. Paraphrase in Conversational Discourse.

\begin{tabular}{|c|}
\hline Burgess, 2003 \\
\hline 32. Vonny: "Have you ever looked into their eyes?" \\
\hline Richard: "Why?" \\
\hline $\begin{array}{l}\text { Vonny: "Of course, Richard never looked anyone in the face" } \\
\text { (p.134). }\end{array}$ \\
\hline Burgess, 2002 \\
\hline Vonè: - Ar tu kada ịsižiūrèjai i jų akis? \\
\hline Ričardas: - O kam? \\
\hline Vonè: Na, taip, Ričardas niekada nežiūri ị žmogü (p.103). \\
\hline
\end{tabular}

Table 8. Paraphrase in Conversational Discourse.

\begin{tabular}{|c|}
\hline Green, 2005 \\
\hline 33. Miles: "We gotta go, Pudge. Time to roll up." \\
\hline Pudge: "Dude. Sleeping." \\
\hline $\begin{array}{l}\text { Miles: "You can sleep after we check in. IT'S TIME TO } \\
\text { GO!" he shouted (p.149). }\end{array}$ \\
\hline Green, 2010 \\
\hline Mailzas: - Tešliau, laikas kilti. Turime kraustytis. \\
\hline Tešlius: - Biče. Miegu. \\
\hline $\begin{array}{l}\text { Mailzas: - Galèsi pamiegoti, kai prisistatysime. LAIKAS } \\
\text { EITI! - užriko jis (p.168). }\end{array}$ \\
\hline
\end{tabular}

The dialogues in Table 7 and Table 8 are examples of immediate, self-repetitions. The characters repeat themselves, however, different words are used to express the same ideas, i.e., to look into somebody's eyes is changed into to look into somebody's face, whereas in the dialogue between Miles and Pudge time to roll up is changed into a more neutral phrase time to go. The functions that conversations perform are expanding (Example 32) and bounding episodes (Example 33). In the dialogue between Vonny and Richard, the repetition of eyes that is changed into face suggests what kind of person Richard really is. In other words, the context is expanded. The dialogue between Miles and Pudge exemplifies the function of bounding episode where the phrase time to roll up opens the conversation and it's time to go closes it. The translators use the translation strategy of preservation with the aim to achieve a natural translation.

The total number of lexical repetition found in dialogues and strategies for translating repetition are presented below (see Table 9 and Table 10). 
Table 9. Types of Lexical Repetition in Dialogues.

\begin{tabular}{|c|l|c|c|}
\hline No. & \multicolumn{1}{|c|}{ Type } & $\begin{array}{c}\text { Number of } \\
\text { examples }\end{array}$ & $\begin{array}{c}\text { Percentage, } \\
\%\end{array}$ \\
\hline 1. & Exact repetition & 18 & 30 \\
\hline 2. & Repetition with variation & 31 & 53 \\
\hline 3. & Paraphrase & 10 & 17 \\
\hline
\end{tabular}

Table 10. Strategies for Translating Repetition in Dialogues.

\begin{tabular}{|c|l|c|c|}
\hline No. & \multicolumn{1}{|c|}{ Strategy } & $\begin{array}{c}\text { Number of } \\
\text { examples }\end{array}$ & Percentage, \% \\
\hline 1. & Preservation & 48 & 81 \\
\hline 2. & Synonymy & 9 & 15 \\
\hline 3. & Substitution & 1 & 2 \\
\hline 4. & Announcing repetition & 1 & 2 \\
\hline
\end{tabular}

\section{Conclusions}

The present article focused on types of lexical repetition in literature for adolescents and its translation from English into Lithuanian. The scientific literature review and analysis of the selected instances allow us to make the following observations:

- Same-unit, simple lexical repetition (59\%) and differentunit repetition, which takes a form of a synonym $(23 \%)$, are the main types of repetition found in the narrative sections of the novels and their translations, whereas conversational discourse is a great source of research on repetition with variation, which proves to be most common in the dialogues $(53 \%)$.

- The translation strategies of preservation (44\%) and synonymy $(25 \%)$ are the most common strategies for translating repetition in the narrative sections. There are also the cases when substitution (6\%), paraphrase $(10 \%)$, announcing the repetition $(5 \%)$ and omission (10\%) are employed. Similar tendencies are observed in the translation of repetition in the dialogues where preservation is applied most often $(81 \%)$.

- The choice of the translation strategy in a particular case is a controversial issue. Sometimes it is important to use a combination of different translation strategies in order to create an aesthetic target text and to achieve a similar effect on the target readership.

- Though traditionally there is a tendency to avoid repetition in everyday life, lexical repetition in literature for young readers is considered as a stylistic device, which makes a literary text more natural and realistic to everyday situations ( $60 \%$ of lexical repetition retained in the target text).

\section{References}

1. Andersen, G., 2001. Pragmatic Markers and Sociolinguistic Variation. Amsterdam: John Benjamins Publishing Company.

2. al-Khafaji, R., 2006. In Search of Translational Norms: The Case of Shifts in Lexical Repetition in Arabic-English Translations. Babel, 52 (1). Amsterdam: John Benjamins, pp. 39-65.

3. Ben-Ari, N., 1998. The Ambivalent Case of Repetitions in Literary Translation. Avoiding Repetitions: A 'Universal' of Translation? Meta, 43 (1), pp.68-78. Available at: http://www.erudit.org/revue/meta/1998/ v43/n1/002054ar.pdf [Accessed on January 2012].

4. Baker, M, 1996. Corpus-based Translation Studies: the Challenges that Lie Ahead. In: Somers, H. (ed.) Terminology, LSP and Translation, Amsterdam: Benjamins, pp.175-186.

5. Davies, E. E., 2003. A Goblin or a Dirty Nose: The Treatment of Culturespecific References in Translations of the Harry Potter Books. The Translator, 9 (1). Manchester: St. Jerome Publishing, pp.65-100.

6. Genç, B., Mavaşoğlu, M., \& Bada, E., 2010. Types and Functions of Repetitions in the Narrations of Turkish Speakers of French. NovitasROYAL (Research on Youth and Language), 2010, 4 (2), pp.216-224. Available at: http://www.novitasroyal.org/Vol_4_2/ genc_mavasoglu_bada.pdf [Accessed on January 2012].

7. Helgegren, S., 2005. Tracing Translation Universals and Translator Development by Word Aligning a Harry Potter. Sweden: Linköping University.

8. Klaudy, K., Károly, K., 2000. The Text-organizing Function of Lexical Repetition in Translation. In: Olohan, M. (ed.) Intercultural Faultlines: Translation Studies I: Textual and Cognitive Aspects. Manchester: St Jerome, pp.143-159.

9. Matthews, P. H., 1997. The Concise Oxford Dictionary of Linguistics. New York: Oxford University Press.

10. Newmark, P., 1988. A Textbook of Translation. Prentice Hall: Hemel Hempstead.

11. Nida, E., 2000. Principles of Correspondence. In: Venuti, L. \& Baker, M. (eds.) The Translation Studies Reader. London: Routledge, pp.153-167.

12. OXFORD 1996 - Oxford English Reference Dictionary. Oxford: Oxford University Press.

13. Shavit, Z., 1981. Translation of Children's Literature as a Function of its Position in the Literary Polysystem. Poetics Today, 2 (4). Durham: Duke University Press, pp. 171-179.

14. Tabbert, R., 2002. Approaches to the Translation of Children's Literature. A Review of Critical Studies since 1960. Target, 14 (2). Amsterdam: John Benjamins, pp.303-351.

15. Tannen, D., 2007. Talking Voices: Repetition, Dialogue, and Imagery in Conversational Discourse. Cambridge: Cambridge University Press 2nd edition. http://dx.doi.org/10.1017/CBO9780511618987

16. Stenström, A., Andersen, G., Hasund, I. K., 2002. Trends in Teenage Talk Corpus Compilation, Analysis and Findings. Amsterdam: John Benjamins Publishing Company.

17. WEBSTER - Webster's Online Dictionary. Available at: http://www.websters-online-dictionary.org/definitions/hyponym [Accessed on January 2012].

\section{Sources}

1. Burgess, M., 2003. Junk. England: Puffin Modern Classics.

2. Green, J., 2010. Aliaskos beieškant. (translation by Gadeikis, D). Vilnius: Alma littera.

3. Green, J., 2005. Looking for Alaska. London: Harper Collins.

4. Burgess, M., 2002. Heroinas. (translation by Patiomkinas, A.). Vilnius: Alma littera.

Karolina Butkuvienè

Vertimo strategijų taikymas verčiant pasikartojimus šiuolaikinèje paauglių literatūroje

Santrauka

Vertèjai neretai tapatinami su tarpininkais tarp skirtingų kultūrų, siekiančiais išversti kalbą ar šneką kaip galima tiksliau. Tačiau tai yra sunkus uždavinys, kadangi dviejų skirtingų kultūrų atstovai gali turèti skirtingą požiūrị ị tuos pačius kultūrinius dalykus. Ne išimtis ir paauglių kalba. 
Paaugliu kalba dažnai kritikuojama dèl kalbos ir šnekos iškraipymo ar „užterštumo“, tačiau retai susimąstoma, kas iš tiesu yra toji paaugliu kalba. Kalbant apie pagrindinius paaugliụ kalbos skiriamuosius bruožus būtina paminèti nebaigtụ sakinių, slengo, vulgarizmų, pastarajai socialinei grupei būdingo žargono bei pasikartojimų vartojimą. Šio tyrimo pagrindinis tikslas yra nustatyti vyraujančius pasikartojimų tipus paauglių kalboje bei išanalizuoti pagrindinius jų vertimo polinkius šiuolaikinèje paauglių literatūroje. Išvadose akcentuojama, jog daugiausia pasikartojimų sudaro tikslūs pasikartojimai, kuriuose kartojamas tas pats žodis, frazė arba kita jų gramatinė forma. Be to, pasitaiko atvejų, kai pasikartojimai perteikiami pasitelkiant sinonimus, antonimus, hiponimus ar perifrazę. Atlikus tyrimą nustatyta, jog polinkis išlaikyti tuos pačius pasikartojimus verstinėje kalboje ir perteikti juos sinonimais yra dažniausiai taikomos vertimo strategijos. Taip pat pasitaiko atvejų, kai pasikartojimai perteikiami pasitelkus pakeitimus, perifrazę arba tiesiog juos praleidus verstinejje kalboje. Kokia vertimo strategija tinkamiausia vienu ar kitu atveju yra diskutuotinas dalykas. Kartais pravartu taikyti keliu strategijų kombinaciją, kad būtu sukurtas estetiškai priimtinas tekstas verstinėje kalboje ir užtikrintas analogiškas poveikis tiksliniam skaitytojui.

Straipsnis ịteiktas 201201

Parengtas spaudai 201205

\section{About the author}

Karolina Butkuviené, MA in Philology, Doctoral student at the Faculty of Humanities, Vytautas Magnus University; assistant lecturer at Siauliai University, Department of English Philology.

Research interests: translation, translation of adolescent literature, intercultural communication.

Address: Šiauliai University, Department of English Philology, P. Višinskio str. 38, 76352 Šiauliai, Lithuania.

E-mail: karolinabutkus@yahoo.com 